\title{
Does Familiarity Foster Innovation? The Impact of Alliance Partner Repeatedness on Breakthrough Innovations
}

\begin{abstract}
Does familiarity with alliance partners lead to breakthrough innovations? This study draws on the literature of interorganizational routines to examine the impact of repeated R\&D collaborations in a firm's alliance portfolio on its breakthrough innovations. Specifically, we contend that the benefits and downsides of interorganizational routines, arising from alliance partner repeatedness at a firm’s alliance portfolio level, will lead to an inverse U-shaped relationship between partner repeatedness and breakthrough innovations. Further, we build on the recent theoretical development of interorganizational routines to propose that technological dynamism will make the inverse U-shaped relationship steeper. Analyses of firms in the U.S. biopharmaceutical industry from 1983 to 2002 support our hypotheses. The findings provide important implications for literatures on alliance portfolio management and firm innovation literatures.
\end{abstract}

Keywords: alliance partner repeatedness, alliance portfolio, breakthrough innovations, environmental dynamism 


\section{INTRODCUTION}

Innovations are becoming increasingly critical for high-tech firms to gain competitive advantages. As the locus of innovation shifts from individual firms to firm networks, firms often form a portfolio of alliances to manage innovation activities (Powell et al., 1996). Prior research has suggested that the characteristics of firms' alliance portfolios will affect the quantity and quality of resources firms can access (Lavie, 2007; Phelps, 2010). How to configure alliance portfolio to achieve superior firm performance therefore becomes a critical strategic issue (Hoffmann, 2007). Indeed, technology firms are increasingly engaged in repeated alliances with prior partners to develop novel technologies (Sampson, 2005). However, we know very little about the impact of alliance partner repeatedness (defined as the extent of repeated $R \& D$ collaborations in an alliance portfolio) on firm innovation, although researchers have investigated the role of repeated collaborations on different firm outcomes and at different levels of analyses (Cowan and Jonard, 2009; Goerzen, 2007; Vanneste and Puranam, 2010). In this research, we specifically ask: to what extent that the repeated alliances with existing partners in a firm's alliance portfolios will influence innovation output, particularly breakthrough innovations?

The research question is practically meaningful. Millennium Pharmaceuticals, for example, is famous for its ability to produce breakthrough innovations in the gene technology field. It is also well known for its open innovation strategy in terms of collaborating with other biotech start-ups, pharmaceutical companies, and research institutes. Millennium pharmaceuticals partnered twice with Abgenix, a biopharmacuetial start-up between 1998 and 2000 on Xenomouse technology. Millennium pharmaceuticals also worked with Eli Lilly on three different R\&D collaborations on various gene technologies from 1991 to 1998. Our study therefore will investigate whether 
alliance portfolio repeatedness will affect developing breakthrough innovations for technology firms such as Millennium Pharmaceuticals.

We argue that there exist at least two important gaps in this area. First, prior research has provided a partial account of how a firm’s alliance partner repeatedness may impact breakthrough innovations. While some researchers have investigated how partner repeatedness may reduce transaction costs and improve coordination that facilitate the innovation process (Vanneste and Puranam, 2010; Wuyts et al., 2004), others have shown that repeated ties inhibit innovation by instilling inert mental models and locking firms into prior trajectories (Goerzen, 2007; Laursen and Salter, 2006; Uzzi and Lancaster, 2003). It remains unclear whether repeated collaborations in a firm's alliance portfolio facilitate breakthrough innovations. In particular, it is critically important to develop a perspective that captures the tension between the benefits and liabilities associated with alliance partner repeatedness for developing breakthrough innovations.

Second, prior studies have rarely investigated the boundary conditions of a firm’s repeated collaborations on its innovations. Although Goerzen (2007) has examined the impact of repeated partnership on a firm's economic performance and its contingencies, our study speaks directly to a firm’s breakthrough innovations, which are closely related to routine development in R\&D alliances. We contend that it is premature to conclude whether alliance partner repeatedness promotes or inhibits breakthrough innovations without examining its context. Indeed, some of the inconsistencies surrounding the impact of repeated collaborations on innovation may arise from different contextual factors. Without a thorough understanding of the contingent effects we cannot precisely assess the consequences of a firm's alliance partner repeatedness and effectively manage alliance portfolio configurations. 
In this study we attempt to address the gaps above by asking: does a firm’s familiarity with R\&D partners in its alliance portfolio promote or inhibit its breakthrough innovations? We draw on the literature of interorganizational routines to propose a curvilinear relationship. Specifically, on the one hand, due to the challenges of complexity, coordination, and uncertainty involved with developing breakthrough innovations, a certain degree of alliance partner repeatedness is necessary for firms to develop interorganizational routines, which facilitate efficient coordination of complex innovation activities such as formalization of search behavior and monitoring of ongoing collaboration process (Zollo et al., 2002). On the other hand, too much partner repeatedness in an alliance portfolio may backfire when the interorganizational routines between the focal firm and its partners is undermined by inertia and rigidity (Baum and Wally, 2003). We therefore predict that there is an inverse U-shaped relationship between a firm's alliance partner repeatedness and its breakthrough innovations.

We further investigate the contingent effect of technological dynamism in the above curvilinear relationship. Technological dynamism poses significant challenges for interfirm collaborations in breakthrough innovations. Departing from prior research that has primarily focused on the inferior learning quality among repeated partners under a dynamic environment (e.g. Goerzen, 2007), recent literature on interorganizational routines has suggested that routines are inherently generative in nature, and are increasingly seen as capable of being adaptive to changing environment (Howard-Grenville, 2005). We argue that the importance of interorganizational routines will be more salient in a dynamic environment than in a stable environment because routines help reduce uncertainties, and free limited cognitive resources for new solutions (Feldman and Pentland, 2003; Lewin et al., 2011). Interorganizational routines not only provide simple rules for firms to cope with uncertainties in a high-velocity environment 
(Davis et al., 2009; Eisenhardt, 1989), but also enable firms to develop concerted efforts to reach out for new knowledge in a dynamic environment (Zollo et al., 2002). We thus contend that before interorganizational routines become rigid technological dynamism will increase the value of partner repeatedness for breakthrough innovations.

Our study contributes to the alliance portfolio literature by proposing an interorganizational routines perspective to examine the impact of partner repeatedness in alliance portfolio on firm innovation, particularly breakthrough innovations (Hoffmann, 2007). This perspective enables us to develop a curvilinear relationship between partner repeatedness and breakthrough innovations that extends beyond the linear effect found in prior studies (Goerzen, 2007). We further build upon this perspective to propose that technological dynamism, which highlights the importance of interorganizational routines arising from repeated partner interactions, will shape the impact of alliance portfolio repeatedness. Together our study extends the alliance portfolio literature and provides a nuanced understanding on how alliance portfolio affects firm innovation.

\section{THEORY AND HYPOTHESES}

Firms are motivated to collaborate in order to develop breakthrough innovations, which is defined as high-impact innovations with the potential to introduce new technological trajectories or paradigm shifts (Ahuja and Lampert, 2001; Dunlap-Hinkler et al., 2010; Phene et al., 2006). Interfirm collaborations enable firms to combine their existing resources into novel configurations, share the costs and risks of uncertain R\&D activities, and expedite the introduction of new technologies.

To realize the potential of interfirm collaboration for breakthrough innovations, firms need to expend a significant amount of time and effort to locate, comprehend, and assimilate partners' 
knowledge before successfully producing a novel recombination or regeneration out of the knowledge pool. This process is full of complexity and uncertainty, which demands smooth and continuous coordination between firms. Knowledge recombination will become less effective if participating firms do not develop interorganizational routines that facilitate coordination during this complex process (Zollo et al., 2002). The uncertainty associated with developing breakthrough innovations also requires that partner firms join hands in formulating and updating their collaboration routines for generating new knowledge in the knowledge discovery process.

The above challenges suggest that a certain degree of repeated collaborations in a firm's alliance portfolio may promote the development of breakthrough innovations. Specifically, we contend that breakthrough innovations are less likely to occur with first-time acquaintances. A certain degree of repeatedness within a firm's alliance portfolio helps establish the interorganizational routines that are critical for managing the ambiguities in developing breakthrough innovations.

Interorganizational routines are repetitive patterns of interdependent actions that have been reinforced through structural embeddedness and repeated interaction (Dionysiou and Tsoukas, 2013; Feldman and Pentland, 2003). A firm that forms repeated collaborations with prior partners often develops structural arrangements such as alliance offices or assigns specific personnel for liaison purpose. These structural arrangements have been proved to be an effective and efficient alliance management approach (Kale et al., 2002). Firms are likely to develop "who knows what” or shared directory knowledge about each other's knowledge stock (Gino et al., 2010). Repeated interactions make it possible for partner firms to better understand their own behaviors and also the best practices for joint activities and contexts (Dionysiou and Tsoukas, 2013; Faems et al., 2012). Through selection, replication, abstraction and generalization of these 
best practices, firms will develop repetitive patterns to guide their subsequent interfirm collaboration.

Interorganizational routines are manifested in various forms, ranging from simple rules such as repetitive patterns for day-to-day operating procedures, to higher level routines or metaroutines that guide the adaptation of lower-level routines to changing external environment (Lewin et al., 2011). The meta-routines reflect the general and abstract nature of routines, while the practiced routines are observable and context specific. In a similar vein, Feldman and Pentland (2003) proposed that routines consist of either ostensive or performative aspect. The ostensive aspect of routines captures the routines in principle, reflects the schematic form of the routine, and is abstract and general in nature. The shared schemata in interfirm relationships enable a common understanding and reciprocal expectations of joint activities (Dionysiou and Tsoukas, 2013). In contrast, the performative aspect of routines entails the routines in practice, reflects the specific actions, and is specific in nature. Feldman and Pentland (2003, p. 107) argued that "the performative aspect creates, maintains, and modifies the ostensive aspect in practice, in much the same way that speaking creates, maintains, and alters a language.”

The interorganizational routines, generated from repeated interactions among alliance partners promote breakthrough innovation in at least two ways. First, these routines enhance the interfirm coordination for managing complex innovative activities. Interorganizational routines are formed based on partners' reflection about what works and what does not work, why, and how the same best practices can be applied to similar contexts (Kale and Singh, 2007). This knowledge codification process help firms better understand the factors behind their successes and failures in the past, and develop more convenient, and even informal routines to facilitate day-to-day operations (Zollo et al., 2002). The knowledge replication and transfer of these routines reduces 
ambiguities abundant in the knowledge discovery process, and shift organizations' focus to more critical issues.

Second, these interorganizational routines enable firms to learn and adapt to new challenges in the innovation process. Routines are also a source of organizational learning (Feldman, 2000; Levitt and March, 1988). Apart from the traditional view that routines are a source of stability and inertia, recent development in this area has advocated the adaptive nature of routines (Dionysiou and Tsoukas, 2013; Feldman and Pentland, 2003; Lewin et al., 2011). Routines are enacted by agents, who will choose from a repertoire of possible routines for the particular contexts or problems at hand. The performative aspect of routines has also emphasized the characteristics of subjectivity and improvisation in the construction of new routines. In other words, routines are "not mindless, but effortful accomplishments” of prior best practices (Pentland and Rueter, 1994). As noted earlier, firms in repeated interactions are able to build structural arrangements to revisit the goals, values, and assumptions in existing routines and adapt them to new situations in the innovation process, a process like the “double loop learning” (Argyris and Schon, 1978; Feldman, 2000).

While the interorganizational routines may help repeated partners to generate breakthrough innovation by enhancing coordination and facilitating learning, we also admit that there is a risk of over-embeddedness in repeated relationships. When a firm has a high degree of repeatedness in its alliance portfolio, the very structured routines that facilitate communication and coordination between the focal firm and its partners could become so rigid that they filter out novel ideas, leading to a familiarity trap. A firm with a high degree of alliance partner repeatedness may therefore engage in exploitation at the expense of exploration (Koza and Lewin, 1998). These established routines could effectively filter out both wasteful ideas and 
brilliant ones. The related literature on firm aging and innovation reached a similar conclusion that older firms tend to develop rigid structures that impede the development of impactful innovations (Sorensen and Stuart, 2000). Repeated collaborations run the risk of locking firms into prior mental models since familiar partners tend to follow prior patterns of interaction (Skilton and Dooley, 2010). Recent research has even demonstrated that repeated alliances are detrimental to participating firms. For instance, Goerzen (2007) found that repeated alliance experience leads to inferior financial performance in a sample of Japanese multinational firms.

In addition, over-embeddedness in repeated relationships may make it difficult to significantly improve existing routines. Familiar partners may focus more on common knowledge (Stewart and Stasser, 1995), and the nature of adaptation by repeated partners tends to become quite incremental and local (Rosenkopf and Nerkar, 2001). Their collective knowledge may become ossified with initial technological advancements and laden with interorganizational inertia (Mayer and Bercovitz, 2008), and will exhaust the new combinations with existing knowledge and capabilities, leading to the underutilization of a firm's absorptive capacity (Vasudeva and Anand, 2011). Laursen and Salter (2006) found that drawing deeply from certain external sources or channels for innovation activities would initially increase innovative performance, but dampen it in the end. Micro-level studies have also suggested that creative abrasion might be another obstacle for repeated partners in generating new creative ideas (Skilton and Dooley, 2010). A higher degree of repeatedness in a firm's alliance portfolio would therefore inhibit the development of breakthrough innovations, causing a downward slope between alliance partner repeatedness and breakthrough innovations. Thus, it is expected that the routine benefits may increase with the degree of partner repeatedness in a firm's alliance portfolio up to a point that 
such benefits will be outweighed by the inertia and constrained adaptation of these routines at a higher degree of partner repeatedness, leading to an inverse U-shaped relationship.

Hypothesis 1: A firm’s alliance partner repeatedness will exhibit an inverse U-shaped relationship with breakthrough innovations.

\section{The Moderating Effect of Technological Dynamism}

We further delineate one contingency that highlights the tension between the benefits and liabilities associated with alliance partner repeatedness. Firms operating within high-technology industries must often deal with technological dynamism — the rate and unpredictability of changes in the next generation or emerging technologies with the potential to replace existing ones. This resembles the state uncertainty or velocity dimension of uncertainty (Davis et al., 2009; Milliken, 1987). Technological dynamism demands frequent updates of knowledge in order to innovate, and is likely to make the existing routines between the focal firm and its repeated partners rapidly obsolete (Glasmeier, 1991).

We argue that technological dynamism will not only amplify the positive effect of partner repeatedness in the upward curve but also intensify the negative effect of partner repeatedness in the downward curve. When partner repeatedness increases from low to moderate degree (i.e. the upward curve), interorganizational routines will become more beneficial at a high level of environmental dynamism as compared to at a low level for two reasons. First, when the alliance repeatedness increases from low to moderate degree, the routines and simple rules developed from repeated collaborations will be more effective for firms navigating through high-velocity environments than through stable environments (Davis et al., 2009). Given an overload of information flow in a dynamic environment, simple rules help a firm quickly identify the necessary resources for knowledge recombination, make rapid decisions, and capture fleeting 
opportunities (Eisenhardt, 1989). In addition, improved mutual understanding also enables the focal firm to accurately identify pieces of knowledge from its partners’ knowledge pool and integrate them for effective implementation in a dynamic environment. The knowledge codification based on prior experience of successes and failures helps firms "see through the fog" of ambiguities in knowledge discovery (Heimeriks et al., 2012), leading to a higher rate of breakthrough innovations. For example, Zollo et al. (2002) found that scientists from repeated partnering firms could accurately identify skills and expertise that the other possessed, allowing them to quickly respond to emerging opportunities by organizing new research teams or initiating new research projects.

Second, when the alliance repeatedness increases from low to moderate degree, the interorganizational routines generated from partner repeatedness may exhibit flexibility in terms of regenerating new knowledge from partners. A dynamic environment will trigger higher-order routines (Bresman, 2013) or motivate firms to initiate explicit cognitive effort to continuously update their routines because the hazards of inappropriate generalization risk are much higher in a dynamic environment (Zollo et al., 2002). Repeated partners may be able to develop more concerted efforts in capturing new knowledge and revising their routines to address the external challenges (Sampson, 2005). Although the internal information flow between repeated partners may be limited, they are more likely to collectively assimilate and process rapidly-changing external knowledge. For example, Vertex pharmaceuticals often formed repeated alliances with partners such as Kissei Pharmaceutical and Burroughs Wellcome. The increased repeatedness in its alliance portfolio allowed Vertex to quickly adjust the contents of its alliances and address the rapid technological changes in HIV related domains. We thus contend that reliance on improved 
coordination via repeated ties that capture new knowledge may be more effective than reliance on the existing knowledge from partners within a rapidly-changing technological environment.

However, when the alliance partner repeatedness continues to increase from moderate to high level (i.e. the downward curve), environment dynamism will intensify the rigidity of interorganizational routines such that the focal firm will be less likely to assimilate fresh knowledge from external partners. The rigidity embedded in mature interorganizational routines will be strengthened at a high level of technological dynamism. The interorganizational routines with familiar partners may turn out to be more detrimental for developing breakthrough innovations in a dynamic environment as compared to a stable environment for two reasons. First, the rigidity of interorganizational routines will stifle the creativity between the focal firm and its repeated partners even more under a dynamic environment because it will filter out more novel ideas arising from the interfirm interactions. Research on creative destruction has suggested that existing capabilities and routines will be rendered obsolete under technological discontinuities (Tushman and Anderson, 1986). Mature interorganizational routines, developed from portfolio repeatedness, will constrain firms’ adaptation to explore novel interfirm opportunities associated with increased level of environmental dynamism. Second, the repeatedness will induce inertia such that the focal firm will narrow down its search scope and become over-embedded in the familiar relationships. This over-embeddedness and rigid routines are more problematic when technological dynamism is high because there is a heightened demand for incorporating novel knowledge into churning out breakthrough innovations. Firms’ inertia in relying on existing routines will therefore aggravate this adaptation demand, resulting in a decreasing rate of breakthrough innovations. 
Therefore, we contend that the inverse U-shaped relationship between partner repeatedness and breakthrough innovation will become steeper for both upward and downward slopes in a dynamic environment than in a stable environment.

Hypothesis 2: Technological dynamism moderates the inverse U-shaped relationship specified in Hypothesis 1 such that both the upward and downward slopes of the inverse Ushaped relationship will become steeper at a high level of technological dynamism.

\section{METHODS}

\section{Sample}

We collected longitudinal data on public firms within the U.S. biopharmaceutical industry. Using a sample of public firms ensures data availability and reliability. Following prior studies we restricted the sample to firms operating within the human diagnostics and therapeutics sectors (Stuart et al., 1999). This context is appropriate for two primary reasons. First, the U.S. biopharmaceutical industry is widely regarded as alliance intensive. Prior studies have shown that firms form alliances in response to rapid technological changes within industries such as biotechnology. Second, breakthrough innovations are crucial for biopharmaceutical firms to succeed in the market. Firms in these sectors form numerous R\&D alliances in order to codevelop novel and impactful technologies.

We obtained a list of companies from Recombinant Capital (RECAP), a leading information provider on biopharmaceutical industry. We then selected publicly traded firms and tracked them from 1983 to 2002. This procedure yielded a sample of 351 focal firms. We collected patent information for these firms from the U.S. Patent and Trademark Office (USPTO), and removed firms that filed fewer than two patents. Since our unit of analysis is at the alliance portfolio level 
we included only observations when firms developed two or more R\&D alliances. For the remaining firms we collected demographic information using Bioscan, Compustat, initial public offering (IPO) disclosure filings, and firm websites. After triangulating data from these various sources we constructed an unbalanced panel of 1,430 firm-year observations.

\section{Dependent Variable}

Breakthrough Innovations. Since breakthrough innovations are often subjectively defined and product development is extremely long in the biopharmaceutical industry, we opted to use the count of patents filed and eventually granted to a focal firm each year that were above the 97th percentile in the number of forward citations. Our operationalization of breakthrough innovations is compatible with prior research on innovation (Ahuja and Lampert, 2001; Srivastava and Gnyawali, 2011). Specifically, we first determined the technical classes in which our sample firms filed patents. We then collected all U.S. utility patents (over 330,000) within these classes, and scaled a patent's forward citations by the mean value of forward citations based on all patents within the same technical classes and granted years (Hall et al., 2001). We then counted the number of patents that fell above the 97th percentile of weighted forwarded citations within its “cohort” as defined by the granted year and technical class (Srivastava and Gnyawali, 2011).

\section{Independent Variables}

Alliance Partner Repeatedness was coded as the geometric mean of repeated R\&D alliances within a firm's alliance portfolio. Since many alliances do not have termination dates, we used a five-year moving window to construct a firm’s yearly alliance portfolio (Yang et al., 2011). This is mathematically expressed as $\left(\prod R_{i}\right)^{1 / N}$, where $R_{i}$ is the number of $R \& D$ alliances the focal firm 
had with its ith R\&D partner and $\mathrm{N}$ is the total number of R\&D partners. For example, if Firm A has three R\&D partners-Firms B, C, and D in year t. Among them Firms B and C are repeated partners (the fourth alliance with Firm B and the second alliance with Firm C) while Firm D is the first time partner. The value of Alliance Partner Repeatedness for Firm A in year $t$ is $(4 * 2 * 1)^{1 / 3}=2$. This measure reflects the degree of repeatedness within a firm's R\&D alliance portfolio. It is superior to an arithmetic-mean based measure because the geometric mean will give greater weights to even distributions (Fink and Jodeit, 1976). The higher the value is, the more a firm is engaged in repeated R\&D collaborations within its alliance portfolio.

Technological Dynamism was measured to capture the velocity surrounding a firm's technological endeavors via a multi-step approach. We began with the population of all biopharmaceutical patents from the USPTO. For each three-digit patent class we regressed its past five years' number of patents on the calendar year. We then divided the standard error of the regression coefficient by the average number of patents filed within the specific class during the past five years. This measure has been constructed similarly in prior works studying technological dynamism (Keats and Hitt, 1988; Wang and Chen, 2010). We derived the value of Technological Dynamism for the focal firm in year $t$ with the weighted average of technological dynamism scores within each three-digit patent class where the firm filed patents. For example, if Firm A filed four patents, of which one in class 424 and three in class 435 and if the technological dynamism scores for class 424 and 435 are 0.16 and 0.12 in year $t$ respectively, then value of Technological Dynamism for Firm A in year $t$ is $.16 *(1 / 4)+.12 *(3 / 4)=0.13$.

We also experimented with an alternative measure. Following Goerzen (2007) we assume that a large change in patent numbers within an industry is associated with technological changes and uncertainty. We therefore measured technological dynamism using the percentage change of 
patent data within each technology domain in the biopharmaceutical industry. Although differently constructed, both measures of technological dynamisms yielded qualitatively similar results. We opted to report the results from the first measure only.

\section{Control Variables}

We controlled for certain key firm-level factors that may influence the occurrence of breakthrough innovations. First, the innovation literature has documented the importance of firm age on innovation, as well as a curvilinear relationship between firm age and innovation (Sorensen and Stuart, 2000). We therefore included both Firm Age and Firm Age Squared to allow for the impact of firm aging on innovative output. We also included Firm Size measured as the log form of the number of employees, Exploration Intensity measured as the portion of drug discovery alliances out of the total R\&D alliances (Rothaermel and Deeds, 2004), and Current Active $R \& D$ Alliances measured as the number of on-going $R \& D$ alliances of the focal firm. A technology firm's innovative output may be correlated to the resources allocated to R\&D. We therefore included $R \& D$ Intensity that was operationalized based on percentage of firm annual R\&D expense by total sales. Finally, we also included two alliance portfolio variables: Portfolio Knowledge Stock measured as the total number of patents granted to the focal firm's partners; Portfolio Knowledge Diversity was measured following prior studies on alliance portfolio (Srivastava and Gnyawali, 2011; Vasudeva and Anand, 2011). Specifically, we first pooled the patents filed by all R\&D partners together. We then measured the knowledge diversity at the alliance portfolio level by taking the conventional diversity formula of $1-\sum\left(n_{i} / N\right)^{2}$, where $n_{i}$ is the number of patents within each patent class, and $\mathrm{N}$ is the total number of patents filed by all $R \& D$ partners prior to year $t$. 


\section{Analyses}

Since our key dependent variable is a count variable, we adopted a negative binomial regression to estimate the parameters. A negative binomial regression is more appropriate than a Poisson model because the former can deal with the over-dispersion issue commonly found in the latter (Wooldridge, 2002). A potential selection bias might exist in our analyses because we included only firms that formed two or more R\&D alliances. We therefore ran a Heckman two-stage approach. In the first stage we regressed the possibility of being selected to our sample on firm age, geographic density of biopharmaceutical firms within the same region, stock market uncertainty, and the Passage of the National Cooperative Research and Production Act (NCRPA) (Beckman et al., 2004; Podolny, 1994; Sorenson and Audia, 2000). Geographic density is a good instrument as it is less likely to affect the innovation quality, but more likely to affect the possibility of partnering with new firms. The Passage of NCRPA in 1993 is also expected to affect alliance formation, but not the innovation outcome. Our first stage regression and an additional test suggest that both instruments are significantly correlated with the possibility of being included in our sample but not significantly predicting breakthrough innovations. The Stock-Yogo test yielded a Cragg-Donald Wald F-statistic of $13.87(p<0.05)$, suggesting that the group of instruments are strong enough (Stock et al., 2002). We generated the inverse Mills ratio from the first-stage estimation and included it in the second stage. We then used the "xtnbreg" command in Stata 12 to estimate the parameters. In order to allow for any unobserved heterogeneities such as organizational culture, we adopted a fixed-effect specification in our analyses, treating each firm as a subject. 


\section{RESULTS}

Table I presents descriptive statistics of this study. Following Aiken and West (1991) we meancentered the predictor variables before generating interaction terms to facilitate interpretation. A variance inflation factors (VIF) test showed that the average and maximum of VIF were 1.53 and 2.78 respectively, both well below the conventional threshold value of 10 . We also used the “coldiag” procedure in STATA to conduct an alternative multicollinearity diagnostic test that showed a condition number of 12.45 for our complete model, well below the threshold of 30 (Belsley et al., 1980).

\section{INSERT TABLE I ABOUT HERE}

Table II displays the negative binomial estimations. In Model 1 we entered control variables such as Firm Age and $R \& D$ Intensity, and in Model 2 we added our independent variables. As predicted, Alliance Partner Repeatedness Squared exhibits a negative and significant impact $(b=$ -2.57, $p<0.01$ ) on Breakthrough Innovations in Model 2. A log likelihood ratio test yields a score of 13.78 showing significant improvement in terms of model fit over the baseline model or Model 1 at 0.01 level with a degree of freedom of two. One standard deviation increase in Alliance Partner Repeatedness when it is 1 will lead to 0.71 unit increase in Breakthrough Innovations, but the same amount of increase for Alliance Partner Repeatedness when it is 1.54 will lead to an almost 0.78 unit decrease in Breakthrough Innovations. The inverse U-shaped curve reaches its maximum at the value of 1.36 for alliance partner repeatedness. Together our Hypothesis 1 is supported. 
Our Hypothesis 2 states that technological dynamism moderates the impact of partner repeatedness on breakthrough innovations such that the curviness of the inverted-U relationship becomes steeper. The quadratic interaction term between Technological Dynamism and Alliance Partner Repeatedness Squared is indeed negative and statistically significant $(b=-29.25, p<$ 0.05) in Model 5 or the full model. Besides, when we entered only the first order interaction term, it was not significant $(b=3.12, p>0.10)$ at all in model 4. Moreover, a log likelihood ratio test also confirms that model fit improves significantly $(\log$ likelihood statistic $=7.93, p<0.05$, d.f. $=$ 2) from Model 2 to Model 5 when including the interaction terms.

Nonetheless, it is still premature to claim a support for our moderating hypothesis. As prior studies have shown (Hoetker, 2007; Wiersema and Bowen, 2009), interpreting the interaction terms in non-linear regressions require careful examination at specific values of certain variables because the actual interaction effect, expressed as the partial derivative, often includes variables instead of constants as in linear regressions. We therefore checked the significance of the interaction term at three different levels of Alliance Partner Repeatedness and Technological Dynamism respectively (3 by 3 or 9 scenarios in total) in the negative binomial regression context (Hilbe, 2011). Indeed, the interaction effect showed non-linearity by changing its sign but all interaction effects were still significant at 0.05 level. Lastly, Figure 1 shows that the impact of Alliance Partner Repeatedness on Breakthrough Innovations hinges on the level of Technological Dynamism and the curvilinear relationship becomes steeper, therefore supporting our Hypothesis 2.

INSERT TABLE II AND FIGURE 1 ABOUT HERE 


\section{Post Hoc Analyses}

We further substantiated our empirical results by conducting additional tests. First, we experimented with a few alternative measures of breakthrough innovations: adopting U.S. patent classification versus international patent classification, including versus excluding self-citations, and selecting different threshold percentiles (99\%, 98\%, 95\%, and 90\%). Our results remain qualitatively the same. For example, when we chose a 99 percentile or top one percent citation threshold (Ahuja and Lampert, 2001), the estimate of Alliance Partner Repeatedness Squared also exhibited a negative and significant impact $(b=-2.34, p<0.01)$ on Breakthrough Innovations. Besides, the moderating effect of Technological Dynamism on the curvilinear relationship between Alliance Partner Repeatedness and Breakthrough Innovations was similar to previous estimation ( $b=-25.93, p<0.05$ ). Second, to investigate whether our theoretical framework applies to incremental innovations, we conducted a formal test on this possibility. Our measure of incremental innovations is similar to breakthrough innovations in that we counted the number of patents receiving below the 50th percentile of forward citations. We also experimented with 40th and 60th percentiles as the cutoff points. Our results demonstrate that Alliance Partner Repeatedness does not exhibit an inverse U-shaped relationship with regard to Incremental Innovations. The estimate of Alliance Partner Repeatedness Squared was negative and not significant $(b=-0.20, p>0.10)$. Interestingly, when we found that $R \& D$ Intensity seemed to be positively and significantly correlated with Incremental Innovations ( $b=0.07, p<$ 0.05) but did not exhibit the same pattern with regard to Breakthrough Innovations. To rule out other alternatives such as the impact of network cohesiveness, we also included a new control Ego Network Density (Phelps, 2010). As predicted, this new control exhibited a positive and 
significant impact on Breakthrough Innovations but our main findings remain qualitatively unchanged. Together, these results show that alliance partner repeatedness does have a unique effect on breakthrough innovations beyond the conventional R\&D expense explanation.

\section{DISCUSSION}

How does repeated partner interaction in a firm's alliance portfolio lead to breakthrough innovations? Departing from prior research that focused on the impact of repeated collaborations at the dyadic level, our study draws on the literature of interorganizational routines to propose that a firm's alliance partner repeatedness is a mixed blessing for developing breakthrough innovations in that a moderate degree of alliance partner repeatedness will strike a balance between the benefits and liabilities of interorganizational routines, arising from repeated partner interactions. Additionally, the above relationship must be examined along with the external technological environment for a better understanding of this phenomenon.

Our study makes three important contributions. First, our study proposes an overarching framework to examine the impact of alliance partner repeatedness on breakthrough innovations. While most prior studies have either focused on the cost or the opportunity side of repeated interactions, we argue that the benefits and liabilities of interorganizational routines from repeated partner interactions will result in an inverse U-shaped relationship between partner repeatedness and breakthrough innovations. We therefore find that breakthrough innovations are less likely to occur with either first-time acquaintances or much-repeated collaborations within a firm's alliance portfolio. Our study also extends prior work in dyadic level by both examining the repeatedness at the alliance portfolio level and placing breakthrough innovations as the central outcome. Our study therefore answers the calls to examine strategic alliance from a 
portfolio perspective (Cui and O’Connor, 2012; Hoffmann, 2007; Lavie, 2007) as well as examine the impact of a specific alliance portfolio configuration on breakthrough innovations. Our study accordingly advances the prior dyadic learning focus toward portfolio learning, giving a broader view of how firms manage alliance portfolios as a whole within the interorganizational learning context.

Second, we find that technological dynamism moderates the impact of partner repeatedness on breakthrough innovations. At a high degree of technological dynamism the interfirm routines developed via repeated collaborations significantly enhance breakthrough innovations (Eisenhardt, 1989). Although some prior studies have suggested that the potential redundant information flow between repeated partners is harmful when operating within dynamic environments (Goerzen, 2007), our study points to the often-underexplored aspects of repeated collaboration: the importance of simple rules and routines in a dynamic environment as well as the generative nature of interorganizational routines to address external challenges by absorbing new information via concerted actions. Compared to integrating existing knowledge among partner firms, it is more critical for participating firms to jointly search for external information and develop executable plans that capture emerging opportunities in a fast-changing environment. This result is also compatible with findings from similar contexts (Zollo et al., 2002), as well as micro-level evidence on the facilitating role of transactive memory systems for developing creativity (Gino et al., 2010). Interfirm routines become more prominent when technologies change rapidly and the information load is high: this finding therefore improves our understanding of interfirm routines that have often been considered less desirable within dynamic environment. 
Third, our study has also provided further insights for research on exploitation and exploration. Prior work has considered network consolidation (i.e. forming alliances with existing partners in the alliance network) as a form of structure exploitation (Beckman et al., 2004; Lin et al., 2007), implicitly hypothesizing it as detrimental to breakthrough innovations. However, our research suggests that a certain level of familiarity between a firm and its partners is critical for the focal firm to develop breakthrough innovations. Well-managed repeated alliances within a firm's alliance portfolio also hold promises for generating major breakthroughs, particularly when a certain level of structure or routines facilitates knowledge assimilation and integration. Our study therefore contributes to an in-depth understanding of how structure exploitation can affect breakthrough innovations, as well as how firms can strategically manage the tradeoff involved in this process (Rothaermel and Deeds, 2004).

Our study also offers insights for practitioners when managing their innovations. We suggest that an alliance portfolio perspective is particularly meaningful for examining innovations because innovation outputs may be a result of cross-fertilization and synergies among various alliances. The partner repeatedness in a firm's portfolio fosters routine formation among partner firms for breakthrough innovations. Our post hoc analyses on incremental innovations also demonstrate that developing breakthrough innovations might follow different paths beyond the conventional R\&D expense. Attention should also be paid to the interfirm interactions and learning mechanisms most conducive to developing mutual understanding, coordination, and interfirm trust in order to promote breakthrough innovations.

\section{Limitations and Future Research}


Despite its merits our study has a few limitations that also hold promise for future research. First, our research relies on one industry that is well known for innovative activities and a high frequency of strategic alliances. Future studies may examine whether or not our proposed theory holds true in other contexts such as low tech industries or other performance dimensions (Goerzen, 2007). Second, although we limited our sample to public firms in order to ensure the availability and reliability of financial data, we believe that the mechanisms proposed in this study can also be effectively applied to private firms. Future research may further investigate the generalizability of our theory. Third, due to the uniqueness of the U.S. biopharmaceutical industry our measures have primarily relied on patent data. Although they serve as a close proxy, patents might not be a comprehensive measure for firm innovative output in some industries where firms rarely file patents. Moreover, our treatment of the second stage regression should be viewed cautiously. After all, prior studies suggested that ordinary least regression (OLS) should be adopted in the second stage (Bushway et al., 2007). We have experimented with such a suggestion but opted to report the results from negative binomial regression that better accounts for a count variable as the dependent variable (Wooldridge, 2002).

Limitations aside, future work may explore different mechanisms leading to incremental versus breakthrough innovations. We focused on breakthrough innovations in this study because the tension between benefits and liabilities is more intense in breakthrough innovations. However, we do predict that incremental innovation may demonstrate different patterns. Our post hoc analyses confirmed this speculation: alliance partner repeatedness demonstrates a hypothesized inverse U-shaped relationship with regard to breakthrough innovations but not to incremental innovations. Additional work is warranted to further investigate how alliance portfolio configurations may affect different types of firm innovations. 


\section{Conclusion}

Does familiarity with alliance partners lead to breakthrough innovations? Our study unravels this puzzle from the perspective of interorganizational routines, and suggests that the tradeoff between the benefits and liabilities of interorganizational routines, arising from repeated collaborations within a firm's alliance portfolio, significantly influences the innovation outcome of a firm, particularly breakthrough innovations. A moderate level of partner repeatedness was found to strike an optimal balance between the benefits and liabilities of interorganizational routines. Our study also reveals the distinct role of technological dynamism in moderating the above relationship in terms of steepening the curvilinear relationship. The most significant message from this study is that partner repeatedness is a double-edged sword for breakthrough innovations. A firm must strategically configure its alliance portfolio by considering an appropriate mix of partner repeatedness and technological dynamism in order to generate breakthrough innovations. 


\section{REFERENCES}

Ahuja, G. and Lampert, C. M. (2001). 'Entrepreneurship in the large corporation: a longitudinal study of how established firms create breakthrough inventions'. Strategic Management Journal, 22, 521-543.

Aiken, L. S. and West, S. G. (1991). Multiple Regression: Testing and Interpreting Interactions. Newbury Park, CA: Sage Publications.

Argyris, C. and Schön, D. A. (1978). Organizational Learning: A Theory of Action Perspective. Reading, MA: Addison-Wesley.

Baum, R. J. and Wally, S. (2003). 'Strategic decision speed and firm performance'. Strategic Management Journal, 24, 1107-1129.

Beckman, C. M., Haunschild, P. R. and Phillips, D. J. (2004). 'Friends or strangers? Firmspecific uncertainty, market uncertainty, and network partner selection'. Organization Science, 15, 259-275.

Belsley, D. A., Kuh, E. and Welsch, R. E. (1980). Regression Diagnostics: Identifying Influential Data and Sources of Collinearity. New York: Wiley.

Bresman, H. (2013). 'Changing routines: a process model of vicarious group learning in pharmaceutical R\&D'. Academy of Management Journal, 56, 35-61.

Bushway, S., Johnson, B. D. and Slocum, L. A. (2007). 'Is the magic still there? The use of the Heckman two-step correction for selectionbias in criminology'. Journal of Quantitative Criminology, 23, 157-178.

Cowan, R. and Jonard, N. (2009). 'Knowledge portfolios and the organization of innovation networks'. Academy of Management Review, 34, 320-342. 
Cui, A. S. and O’Connor, G. (2012). 'Alliance portfolio resource diversity and firm innovation'. Journal of Marketing, 76, 24-43.

Davis, J. P., Eisenhardt, K. M. and Bingham, C. B. (2009). 'Optimal structure, market dynamism, and the strategy of simple rules'. Administrative Science Quarterly, 54, 413-452.

Dionysiou, D. D. and Tsoukas, H. (2013). 'Understanding the (re)creation of routines from within: a symbolic interactionist perspective'. Academy of Management Review, 38, 181-205.

Dunlap-Hinkler, D., Kotabe, M. and Mudambi, R. (2010). 'A story of breakthrough versus incremental innovation: corporate entrepreneurship in the global pharmaceutical industry'. Strategic Entrepreneurship Journal, 4, 106-127.

Eisenhardt, K. M. (1989). 'Making fast strategic decisions in high-velocity environments'. Academy of Management Journal, 32, 543-576.

Faems, D., Janssens, M. and Neyens, I. (2012). 'Alliance portfolios and innovation performance connecting structural and managerial perspectives'. Group \& Organization Management, 37, 241-268.

Feldman, M. S. (2000). 'Organizational routines as a source of continuous change'. Organization Science, 11, 611-629.

Feldman, M. S. and Pentland, B. T. (2003). 'Reconceptualizing organizational routines as a source of flexibility and change'. Administrative Science Quarterly, 48, 94-118.

Fink, A. M. and Jodeit, M. (1976). 'A generalization of the arithmetic-geometric means inequality'. Proceedings of the American Mathematical Society, 61, 255-261.

Gino, F., Argote, L., Miron-Spektor, E. and Todorova, G. (2010). 'First, get your feet wet. the effects of learning from direct and indirect experience on team creativity'. Organizational Behavior and Human Decision Processes, 111, 102-115. 
Glasmeier, A. (1991). 'Technological discontinuties and flexible production networks: the case of Switzerland and the world watch industry'. Research Policy, 20, 469-485.

Goerzen, A. (2007). 'Alliance networks and firm performance: the impact of repeated partnerships'. Strategic Management Journal, 28, 487-509.

Hall, B. H., Jaffe, A. B. and Traijtenberg, M. (2001). The nber patent citations data file: lessons, insights and methodological tools. Working Paper No.8498, NBER.

Heimeriks, K. H., Schijven, M. and Gates, S. (2012). 'Manifestations of higher-order routines: the underlying mechanisms of deliberate learning in the context of postacquisition integration'. Academy of Management Journal, 55, 703-726.

Hilbe, J. M. (2011). Negative Binomial Regression. New York: Cambridge University Press. Hoetker, G. (2007). 'The use of logit and probit models in strategic management research: critical issues'. Strategic Management Journal, 28, 331-343.

Hoffmann, W. H. (2007). 'Strategies for managing a portfolio of alliances'. Strategic Management Journal, 28, 827-856.

Howard-Grenville, J. A. (2005). 'The persistence of flexible organizational routines: the role of agency and organizational context'. Organization Science, 16, 618-636.

Kale, P., Dyer, J. H. and Singh, H. (2002). 'Alliance capability, stock market response, and long term alliance success: the role of the alliance function'. Strategic Management Journal, 23, 747767.

Kale, P. and Singh, H. (2007). 'Building firm capabilities through learning: the role of the alliance learning process in alliance capability and firm-level alliance success'. Strategic Management Journal, 28, 981-1000. 
Keats, B. W. and Hitt, M. A. (1988). 'A causal model of linkages among environmental dimensions, macro organizational characteristics and performance'. Academy of Management Journal, 31, 570-598.

Koza, M. P. and Lewin, A. Y. (1998). 'The co-evolution of strategic alliances'. Organization Science, 9, 255-264.

Laursen, K., and Ammon Salter. (2006). 'Open for innovation: the role of openness in explaining innovation performance among UK manufacturing firms'. Strategic Management Journal, 27, 131-150.

Lavie, D. (2007). 'Alliance portfolios and firm performance: a study of value creation and appropriation in the US software industry'. Strategic Management Journal, 28, 1187-1212. Levitt, B. and March, J. G. (1988). 'Organizational learning'. Annual Review of Sociology, 14, 319-340.

Lewin, A. Y., Massini, S. and Peeters, C. (2011). 'Microfoundations of internal and external absorptive capacity routines'. Organization Science, 22, 81-98.

Lin, Z., Yang, H. and Demirkan, I. (2007). 'The performance consequences of ambidexterity in strategic alliance formations: empirical investigation and computer simulation'. Management Science, 53, 1645-1658.

Mayer, K. J. and Bercovitz, J. (2008). 'The influence of inertia on contract design: contingency planning in information technology service contracts'. Managerial \& Decision Economics, 29, 149-163.

Milliken, F. J. (1987). 'Three types of perceived uncertainty about the environment: state, effect, and response uncertainty'. Academy of Management Review, 12, 133-143. 
Pentland, B. T. and Rueter, H. H. (1994). 'Organizational routines as grammars of action'. Administrative Science Quarterly, 39, 484-510.

Phelps, C. C. (2010). 'A longitudinal study of the influence of alliance network structure and composition on firm exploratory innovation'. Academy of Management Journal, 53, 890-913. Phene, A., Fladmoe-Lindquist, K. and Laurence, M. (2006). 'Breakthrough innovations in the US biotechnology industry: the effects of technological space and geographic origin'. Strategic Management Journal, 27, 369-388.

Podolny, J. M. (1994). 'Market uncertainty and the social character of economic exchange'. Administrative Science Quarterly, 39, 458-483.

Powell, W. W., Koput, K. W. and Smith-Doerr, L. (1996). 'Interorganizational collaboration and the locus of innovation: networks of learning in biotechnology'. Administrative Science Quarterly, 41, 116-145.

Rosenkopf, L. and Nerkar, A. (2001). 'Beyond local search: boundary-spanning, exploration, and impact in the optical disk Industry'. Strategic Management Journal, 22, 287-306.

Rothaermel, F. T. and Deeds, D. L. (2004). 'Exploration and exploitation alliances in biotechnology: a system of new product development'. Strategic Management Journal, 25, 201221.

Sampson, R. C. (2005). 'Experience effects and collaborative returns in R\&D alliances'. Strategic Management Journal, 26, 1009-1031.

Skilton, P. F. and Dooley, K. J. (2010). 'The effects of repeat collaboration on creative abrasion'. Academy of Management Review, 35, 118-134.

Sorensen, J. B. and Stuart, T. E. (2000). 'Aging, obsolescence, and organizational innovation'. Administrative Science Quarterly, 45, 81-112. 
Sorenson, O. and Audia, P. G. (2000). 'The social structure of entrepreneurial activity: geographic concentration of footwear production in the United States, 1940-1989'. American Journal of Sociology, 106, 424-461.

Srivastava, M. K. and Gnyawali, D. R. (2011). 'When do relational resources matter? Leveraging portfolio technological resources for breakthrough innovation'. Academy of Management Journal, 54, 797-810.

Stewart, D. D. and Stasser, G. (1995). 'Expert role assignment and information sampling during collective recall and decision-making'. Journal of Personality and Social Psychology, 69, 619628.

Stock, J. H., Wright, J. H. and Yogo, M. (2002). 'A survey of weak instruments and weak identification in generalized method of moments'. Journal of Business and Economic Statistics, 20, 518-529.

Stuart, T. E., Hoang, H. and Hybels, R. C. (1999). 'Interorganizational endorsements and the performance of entrepreneurial ventures'. Administrative Science Quarterly, 44, 315-349. Tushman, M. and Anderson, P. (1986). 'Technological discontinuties and organizational environments'. Administrative Science Quarterly, 31, 439-465.

Uzzi, B. and Lancaster, R. (2003). 'Relational embeddedness and learning: the case of bank loan managers and their clients'. Management Science, 49, 383-399.

Vanneste, B. S. and Puranam, P. (2010). 'Repeated interactions and contractual detail: identifying the learning effect'. Organization Science, 21, 186-201. Vasudeva, G. and Anand, J. (2011). 'Unpacking absorptive capacity: a study of knowledge utilization from alliance portfolio'. Academy of Management Journal, 54, 611-623. 
Wang, H. L. and Chen, W. R. (2010). 'Is firm-specific innovation associated with greater value appropriation? The roles of environmental dynamism and technological diversity'. Research Policy, 39, 141-154.

Wiersema, M. F. and Bowen, H. P. (2009). 'The use of limited dependent variable techniques in strategy research: issues and methods'. Strategic Management Journal, 30, 679-692.

Wooldridge, J. M. (2002). Econometric Analysis of Cross Section and Panel Data. Boston, MA: MIT Press.

Wuyts, S., Dutta, S. and Stremersch, S. (2004). 'Portfolios of interfirm agreements in technologyintensive markets: consequences for innovation and profitability'. Journal of Marketing, 68, 88100.

Yang, H., Lin, Z. and Peng, M. W. (2011). 'Behind acquisitions of alliance partners: exploratory learning and network embeddedness'. Academy of Management Journal, 54, 1069-1080. Zollo, M., Reuer, J. J. and Singh, H. (2002). 'Interorganizational routines and performance in strategic alliances'. Organization Science, 13, 701-713. 
Table I: Descriptive statistics and correlations

\begin{tabular}{|c|c|c|c|c|c|c|c|c|c|c|c|c|c|c|}
\hline VARIABLES & Mean & S.D. & 1 & 2 & 3 & 4 & 5 & 6 & 7 & 8 & 9 & 10 & 11 & 12 \\
\hline $\begin{array}{l}\text { 1. Breakthrough } \\
\text { Innovations }\end{array}$ & 1.81 & 7.34 & & & & & & & & & & & & \\
\hline 2. Firm Age & 19.16 & 29.74 & 0.35 & & & & & & & & & & & \\
\hline 3. Firm Age Squared/100 & 12.51 & 39.3 & 0.30 & 0.98 & & & & & & & & & & \\
\hline 4. Firm Size & -1.35 & 2.17 & 0.37 & 0.71 & 0.69 & & & & & & & & & \\
\hline 5. Exploration Intensity & 0.51 & 0.29 & -0.07 & -0.1 & -0.08 & -0.12 & & & & & & & & \\
\hline $\begin{array}{l}\text { 6. Current Active R\&D } \\
\text { Alliances }\end{array}$ & 1.38 & 2.16 & 0.22 & 0.25 & 0.25 & 0.30 & -0.05 & & & & & & & \\
\hline 7. R\&D Intensity & 15.13 & 1.62 & 0.39 & 0.67 & 0.63 & 0.56 & -0.09 & 0.29 & & & & & & \\
\hline $\begin{array}{l}\text { 8. Portfolio Knowledge } \\
\text { Stock }\end{array}$ & 8.56 & 3.85 & -0.06 & -0.13 & -0.12 & -0.15 & -0.01 & -0.18 & -0.15 & & & & & \\
\hline $\begin{array}{l}\text { 9. Portfolio Knowledge } \\
\text { Diversity }\end{array}$ & 0.89 & 0.13 & 0.07 & -0.03 & -0.05 & -0.01 & -0.05 & 0.14 & 0.11 & -0.31 & & & & \\
\hline 10. Inverse Mills Ratio & -0.25 & 0.25 & 0.10 & 0.12 & 0.11 & 0.08 & -0.09 & 0.12 & 0.23 & -0.03 & 0.28 & & & \\
\hline $\begin{array}{l}\text { 11. Alliance Partner } \\
\text { Repeatedness }\end{array}$ & 1.03 & 0.11 & 0.05 & 0.03 & 0.02 & 0.05 & -0.01 & 0.01 & 0.04 & 0.01 & 0.04 & 0.01 & & \\
\hline $\begin{array}{l}\text { 12. Alliance Partner } \\
\text { Repeatedness Squared }\end{array}$ & 1.07 & 0.33 & 0.04 & 0.03 & 0.02 & 0.04 & -0.01 & 0.01 & 0.03 & 0.02 & 0.03 & 0.01 & 0.99 & \\
\hline $\begin{array}{l}\text { 13. Technological } \\
\text { Dynamism }\end{array}$ & 0.11 & 0.08 & 0.02 & -0.10 & -0.10 & -0.07 & 0.04 & 0.06 & -0.04 & 0.01 & 0.15 & 0.28 & 0.03 & 0.03 \\
\hline
\end{tabular}

Note: $\mathrm{N}=1,430$. Correlations above $|.06|$ are significant at the .05 level 
Table II: Negative binomial model estimating Breakthrough Innovations

\begin{tabular}{|c|c|c|c|c|c|}
\hline VARIABLES & Model 1 & Model 2 & Model 3 & Model 4 & Model 5 \\
\hline Firm Age & $\begin{array}{r}-0.02^{*} \\
(-1.98)\end{array}$ & $\begin{array}{l}-0.02 \\
(-1.45)\end{array}$ & $\begin{array}{l}-0.02 \\
(-1.46)\end{array}$ & $\begin{array}{l}-0.02 \\
(-1.42)\end{array}$ & $\begin{array}{l}-0.02 \\
(-1.64)\end{array}$ \\
\hline Firm Age Squared/100 & $\begin{array}{r}0.02 * * \\
(3.03)\end{array}$ & $\begin{array}{r}0.02 * * \\
(2.64)\end{array}$ & $\begin{array}{r}0.02 * * \\
(2.68)\end{array}$ & $\begin{array}{r}0.02 * * \\
(2.66)\end{array}$ & $\begin{array}{r}0.02 * * \\
(2.81)\end{array}$ \\
\hline Firm Size & $\begin{array}{r}0.09 \dagger \\
(1.89)\end{array}$ & $\begin{array}{r}0.10 * \\
(2.12)\end{array}$ & $\begin{array}{r}0.11^{*} \\
(2.29)\end{array}$ & $\begin{array}{c}0.11^{*} \\
(2.24)\end{array}$ & $\begin{array}{r}0.11^{*} \\
(2.38)\end{array}$ \\
\hline Exploration Intensity & $\begin{array}{r}0.51 * \\
(2.37)\end{array}$ & $\begin{array}{r}0.48 * \\
(2.31)\end{array}$ & $\begin{array}{c}0.45^{*} \\
(2.20)\end{array}$ & $\begin{array}{c}0.45^{*} \\
(2.24)\end{array}$ & $\begin{array}{r}0.49 * \\
(2.38)\end{array}$ \\
\hline Current Active R\&D Alliances & $\begin{array}{r}0.02 \dagger \\
(1.72)\end{array}$ & $\begin{array}{c}0.03 * \\
(2.20)\end{array}$ & $\begin{array}{c}0.03 * \\
(2.34)\end{array}$ & $\begin{array}{c}0.03 * \\
(2.16)\end{array}$ & $\begin{array}{r}0.02 \dagger \\
(1.93)\end{array}$ \\
\hline R\&D Intensity & $\begin{array}{l}-0.00 \\
(-0.04)\end{array}$ & $\begin{array}{l}-0.01 \\
(-0.13)\end{array}$ & $\begin{array}{r}0.02 \\
(0.30)\end{array}$ & $\begin{array}{r}0.02 \\
(0.31)\end{array}$ & $\begin{array}{r}0.01 \\
(0.19)\end{array}$ \\
\hline Portfolio Knowledge Stock & $\begin{array}{r}0.03 * * \\
(2.65)\end{array}$ & $\begin{array}{r}0.04 * * \\
(2.93)\end{array}$ & $\begin{array}{r}0.04 * * \\
(2.84)\end{array}$ & $\begin{array}{r}0.03 * * \\
(2.79)\end{array}$ & $\begin{array}{r}0.03 * * \\
(2.70)\end{array}$ \\
\hline Portfolio Knowledge Diversity & $\begin{array}{r}0.25 \\
(0.90)\end{array}$ & $\begin{array}{r}0.28 \\
(1.00)\end{array}$ & $\begin{array}{r}0.23 \\
(0.86)\end{array}$ & $\begin{array}{r}0.24 \\
(0.88)\end{array}$ & $\begin{array}{r}0.23 \\
(0.88)\end{array}$ \\
\hline Inverse Mills Ratio & $\begin{array}{r}1.15^{* * *} \\
(4.98)\end{array}$ & $\begin{array}{r}1.15^{* * * *} \\
(5.00)\end{array}$ & $\begin{array}{r}1.01 * * * \\
(4.26)\end{array}$ & $\begin{array}{r}0.99 * * * \\
(4.17)\end{array}$ & $\begin{array}{r}1.01 * * * \\
(4.26)\end{array}$ \\
\hline Alliance Partner Repeatedness & & $\begin{array}{r}7.00 * * \\
(3.22)\end{array}$ & $\begin{array}{r}7.19 * * * \\
(3.39)\end{array}$ & $\begin{array}{r}7.36^{* *} \\
(3.18)\end{array}$ & $\begin{array}{r}7.68 * * * \\
(3.80)\end{array}$ \\
\hline $\begin{array}{l}\text { Alliance Partner Repeatedness } \\
\text { Squared }\end{array}$ & & $\begin{array}{r}-2.57 * * \\
(-3.10)\end{array}$ & $\begin{array}{r}-2.64 * * \\
(-3.24)\end{array}$ & $\begin{array}{r}-2.73 * * \\
(-3.01)\end{array}$ & $\begin{array}{r}-2.87 * * * \\
(-3.75)\end{array}$ \\
\hline Technological Dynamism & & & $\begin{array}{l}1.39 * \\
(2.57)\end{array}$ & $\begin{array}{l}1.38 * \\
(2.55)\end{array}$ & $\begin{array}{l}1.22 * \\
(2.22)\end{array}$ \\
\hline $\begin{array}{l}\text { Technological Dynamism X Alliance } \\
\text { Partner Repeatedness }\end{array}$ & & & & $\begin{array}{r}3.12 \\
(0.65)\end{array}$ & $\begin{array}{r}79.51^{*} \\
(2.13)\end{array}$ \\
\hline $\begin{array}{l}\text { Technological Dynamism X Alliance } \\
\text { Partner Repeatedness Squared }\end{array}$ & & & & & $\begin{array}{r}-29.25 * \\
(-2.07)\end{array}$ \\
\hline Observations & 1430 & 1430 & 1430 & 1430 & 1430 \\
\hline Wald Chi2 & 108.86 & 127.97 & 136.60 & 136.21 & 145.03 \\
\hline Log likelihood & -1338 & -1331 & -1328 & -1327 & -1324 \\
\hline
\end{tabular}

Note: z-values in parentheses; two-tailed test. ${ }^{* * *} p<0.001$; ${ }^{* *} p<0.01$; ${ }^{*} p<0.05$; $\dagger p<0.10$ 
Figure 1: Moderating effect of Technological Dynamism

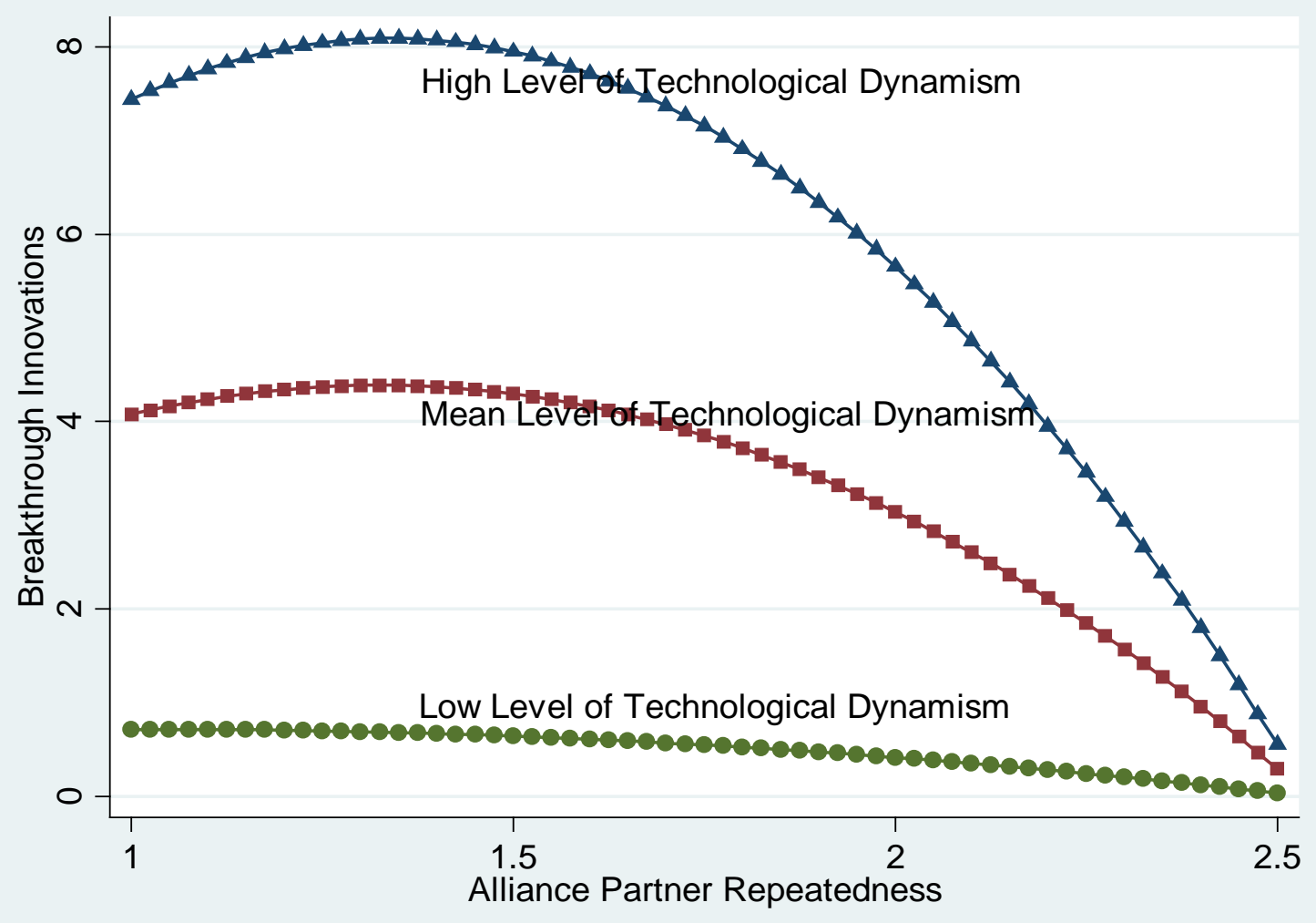

